\title{
Numerical study on stress paths in grounds reinforced with long and short CFG piles during adjacent rigid retaining wall movement
}

https://doi.org/10.2478/sgem-2021-0029

received April 19, 2021; accepted October 19, 2021.

\begin{abstract}
Ensuring the safety of existing structures is an important issue when planning and executing adjacent new foundation pit excavations. Hence, understanding the stress state conditions experienced by the soil element behind a retaining wall at a given location during different excavation stages has been a key observational modelling aspect of the performance of excavations. By establishing and carrying out sophisticated soil-structure interaction analyses, stress paths render clarity on soil deformation mechanism. On the other hand, column-type soft ground treatment has recently got exceeding attention and practical implementation. So, the soil stress-strain response to excavation-induced disturbances needs to be known as well. To this end, this paper discusses the stress change and redistribution phenomena in a treated ground based on 3D numerical analyses. The simulation was verified against results from a $1 \mathrm{~g}$ indoor experimental test conducted on composite foundation reinforced with long and short cement-fly ash-gravel (CFG) pile adjacent to a moving rigid retaining wall. It was observed that the stress path for each monitoring point in the shallow depth undergoes a process of stress unloading at various dropping amounts of principal stress components in a complex manner. The closer the soil element is to the wall, the more it experiences a change in principal stress components as the wall movement progresses; also, the induced stress disturbance weakens significantly as the observation point becomes farther away from the wall.
\end{abstract}

\footnotetext{
*Corresponding author: Yuancheng Guo, School of Civil Engineering, Zhengzhou University, Zhengzhou 450001, China, E-mail: guoyuancheng@163.com Bantayehu Uba Uge, School of Civil Engineering, Zhengzhou University, Zhengzhou 450001, China; School of Civil Engineering, Hawassa University, Hawassa, Ethiopia

Yunlong Liu, School of Civil Engineering, Zhengzhou University, Zhengzhou 450001, China
}

Accordingly, the overall vertical load-sharing percentage of the upper soil reduces proportionally.

Keywords: $\mathrm{CFG}$ pile; composite foundation; cushion; load-sharing ratio; retaining wall; excavation.

\section{Introduction}

The super tall buildings emerging worldwide along with the need for utilising marginal lands of urban districts has presented design and construction challenges to geotechnical engineers. As these structures usually incorporate multi-level basement, the use of the thick base slab as a mat foundation may be reasonable to achieve the required bearing capacity. To satisfy the settlement criteria, however, in some situations, piles may be added beneath the raft in strategical locations to form a composite piled-raft foundation system. ${ }^{[1]}$ Crowned with interposed load transfer platform (LTP) of an appropriate material under the raft, cement-fly ash-gravel (CFG) piles are used as column-type rigid inclusions to reinforce shallow weak soils and receive the upper imposed load indirectly. Recently, Uge and $\mathrm{GuO}^{[2]}$ have made a succinct overview on their area of application in engineering practice. It is revealed that due to the deformability characteristics of the LTP layer, negative side friction (NSF) develops on the upper $15 \%-50 \%$ of the pile length, where settlement of the shallow soil becomes greater than that of the pile owing to the pile head pricking into the LTP layer. ${ }^{[3-7]}$ It has also become a common practice to use a combination of different piles with varying stiffness ${ }^{[8,9]}$ and/or length ${ }^{[10,11]}$ to meet the economic advantages, whereby the natural unfavourable shallow soil is strengthened by the short/ flexible piles and contributes to bear a certain proportion of the foundation load while the long piles serve as foundation settlement reducers.

In one part, unlike the vast literature on the vertical load-bearing and settlement characteristics of CFG piles, 
little information can be gleaned on the lateral loadsharing behaviour of this ground improvement technology. The few previous studies that are available have focused on the lateral reinforcing effect of $\mathrm{CFG}$ piles in reducing the horizontal earth thrust on retaining walls because of their shielding effect. ${ }^{[12,13]}$ Experimental ${ }^{[14,15]}$ and numerical ${ }^{[16]}$ observations have revealed the same. Consequently, the study on evolution and distribution of earth pressure on retaining wall neighbouring composite foundation has recently garnered much attention. ${ }^{[14,17]}$ However, the mutual interaction between existing CFG piles and adjacent retaining wall needs to be well understood in order to ensure their stability. In this regard, recent years have witnessed that the synergistic mechanism influences the vertical load-bearing characteristics throughout the process of neighbouring excavation work. ${ }^{[18-20]}$ The physical model test results of $\mathrm{Li}$ et al. ${ }^{[2]}$ on the load distribution of rigid pile composite foundation revealed the same characteristics under the condition of soil displacement from retaining wall rotation about the base.

On the other hand, the safety of conventional piles subjected to ground movements arising from nearby excavations and other sources has globally received particular interest. ${ }^{[22-28]}$ Researchers such as Shi et al. ${ }^{[29]}$ and Shakeel and $\mathrm{Ng}^{[30]}$ have discussed the load transfer mechanism and the response of single and group pile, respectively, using stress path followed during excavation stages. The soil elements for observation were taken around the pile, and the load-sharing phenomena were captured by comparing the level of stress the soil element encounters. They noticed the rate of stress increment or relief throughout the progression of excavation to infer about the magnitude of downward (from shaft to pile toe) or upward stress transmission. According to the findings from Soomro et al., ${ }^{[3]}$ to sustain the working load during excavation, the deviatoric stress $q$ of a monitoring soil element mid-depth along the pile shaft increases, while the mean effective stress $p$ decreases due to stress release, implying an increase in the pile shaft resistance to support the imposed load. Similar observation was forwarded by $\mathrm{Ng}$ et al., ${ }^{[32]}$ where they indicated the mechanism of load transfer during sequential excavation in both elevated group of pile and a pile cap in contact with the shallow soil. Owing to excavation-induced gap formation underneath the cap, they noticed a dominant transfer of load from raft to pile than redistribution among the piles and justified the pile settlement based on the stress path followed as the excavation progresses.

In fact, as long as excavation execution is concerned, it changes the initial stress sate of the ground. This manmade stress field disturbance has been well known and is being investigated in various ways in geoengineering problems. For instance, Li et al. ${ }^{[33]}$ discussed about excavation activity-induced principal stress path change and its influence on the deformation and stability of road way. Choi et al. ${ }^{[34]}$ studied the stiffness degradation and reported the stress path at different monitoring points around excavation. Cao et al. ${ }^{[35]}$ numerically studied the stress path during various stages of construction, considering a surcharge load from a crane used for lifting in the process of excavation.

So far, enormous efforts have also been made to understand the accompanied principal stress rotations (PSRs) during the process of excavation and to experimentally characterise the soil deformation characteristics under several PSRs occurring in the subsequent foundation pit construction phases. ${ }^{[36,37]}$ Hsieh and $\mathrm{Ou}^{[38]}$ inspected the state of stress and the PSRs for the soil element outside and inside the zone of excavation and have shown that reasonable estimation of excavation-induced ground movements can not only be made by taking into account small strain behaviour, but also without ignoring the stiffness degradation. Ni et al. ${ }^{[39]}$ performed plane strain test under various stress paths to capture the stress-strain response of soil during deep excavation, as in most cases, plane strain loading and unloading condition is encountered in deep excavations with larger length to breadth ratio. They recommended to use unloading stiffness in deformation analysis since their experimental and numerical analysis resulted in a decrease in soil shear strength throughout the process of excavation. Lim and $\mathrm{Ou}^{[40]}$ had reported the stress path for different stress points within the excavation influence zone and the retained side. They showed the cartesian and principal stress representations to explain evolution of change in principal stress directions at subsequent stages of excavation and the tendency of the soil element to undergo movement in the direction of excavation. Such studies and other studies ${ }^{[41,42]}$ have been forwarded to shed light on deformation and strength characteristics of the natural intact soil adjacent to excavations. However, the same study in reinforced soil with rigid column inclusion, whose stress transfer behaviour is highly influenced by the relative pile/soil movement, is very limited.

In this framework, taking the current high interest into consideration to utilise CFG long and short pile composite foundation in urban dwellings and to check its performance during new adjacent deep excavation activities, an indoor experimental investigation was carried out. The large-scale indoor $1 \mathrm{~g}$ model test was conducted for rotation of the retaining wall about the base. The results of the model test were used to calibrate 


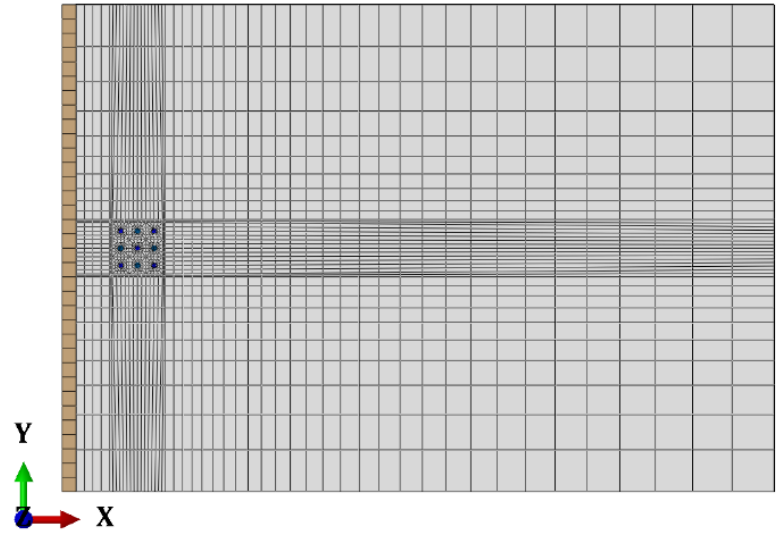

b)

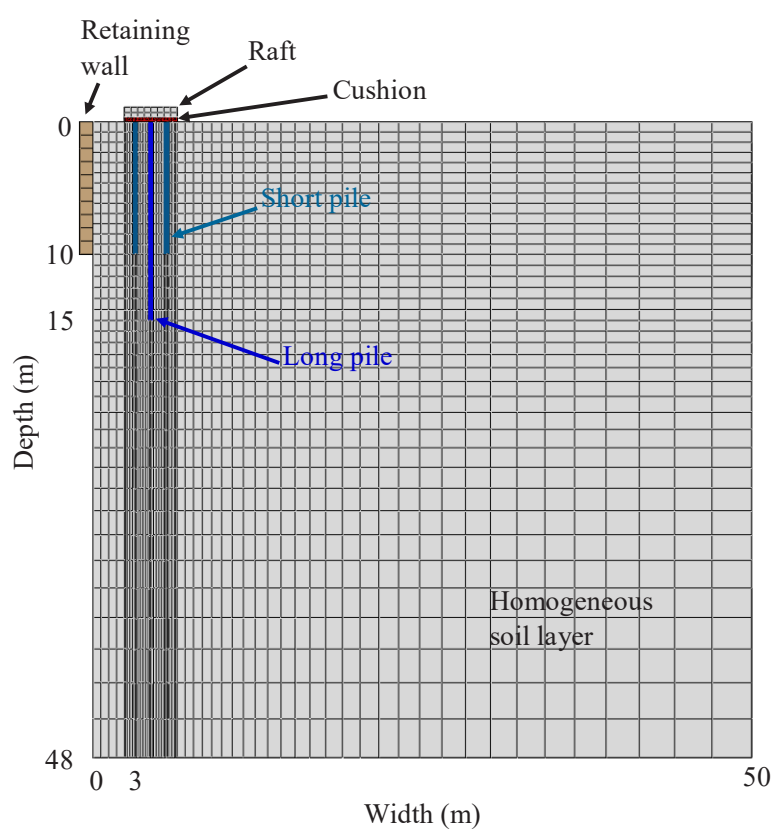

Figure 1: Typical (a) plan and (b) sectional view of finite element mesh used for nine long-short pile composite foundation at 3-m distance away from wall.

the 3D numerical analysis performed with ABAQUS finite element software to analyse the stress paths experienced by selected soil elements in the foundation system.

\section{Methodology of analysis}

\subsection{Finite element modelling}

The commercial FE software ABAQUS was chosen to develop the finite element model. The model comprised structural (pile, raft and wall) and geotechnical (soil and cushion) parts that were modelled as elastic and elastic ideal plastic Mohr-Coulomb constitutive model, respectively. Even though Mohr-Coulomb model is not a state-of-the-art constitutive relation, it has widely been employed in $\mathrm{FE}$ analysis to describe the engineering characteristics of geotechnical materials while investigating the behaviour of composite piled raft foundations ${ }^{[6,10,43-45]}$ and performance of deep foundation pit excavations and/or their influence on the surrounding infrastructures. ${ }^{[26,46,47]}$ Figure 1 depicts the typical meshed geometry employed in the model. The retaining wall in each case was 10-m deep, whereas to avoid boundary effects, the homogeneously treated soil medium was made to be at least as five times wide as the breadth $\mathrm{Br}$ of the raft in the lateral extent and as deep as more than thrice the length of long pile vertically.
Considering computational expensiveness without compromising accuracy, the mesh density in the neighbourhood of structural members was made finer than that for other locations, with a gradual change to coarser mesh sizes. Each mesh part was discretised using an eight-node linear brick element with reduced integration and hourglass control (C3D8R). As the size of the model parts for the cushion, raft and soil increased as the number of piles in the composite foundation was increased, their corresponding mesh discretisation yielded different number of nodes. As a consequence, increasing the number of piles, say from 9 to 25, increased the number of nodes in the model assembly from 98,526 to 155,733 . The surrounding vertical boundaries were modelled to restrain lateral displacements, while the bottom was set to constrain both horizontal and vertical displacements. The top surface boundary was set to be free in each direction. The boundary condition at the base of the wall was defined by a pin support to allow only rotation about its base, while its side, the boundary which was in direct contact with the retained soil mass behind the wall, was defined by establishing a contact surface algorithm characterised by the general surface-to-surface contact formulation. The analysis was initiated by generating $\mathrm{K}_{0}$ geostatic stress field within the soil that produced very small deformation but in equilibrium stress field with gravity loading. This initial condition was followed by introducing sequentially the piles, cushion layer and raft by establishing surface-to-surface contacts along 
a)
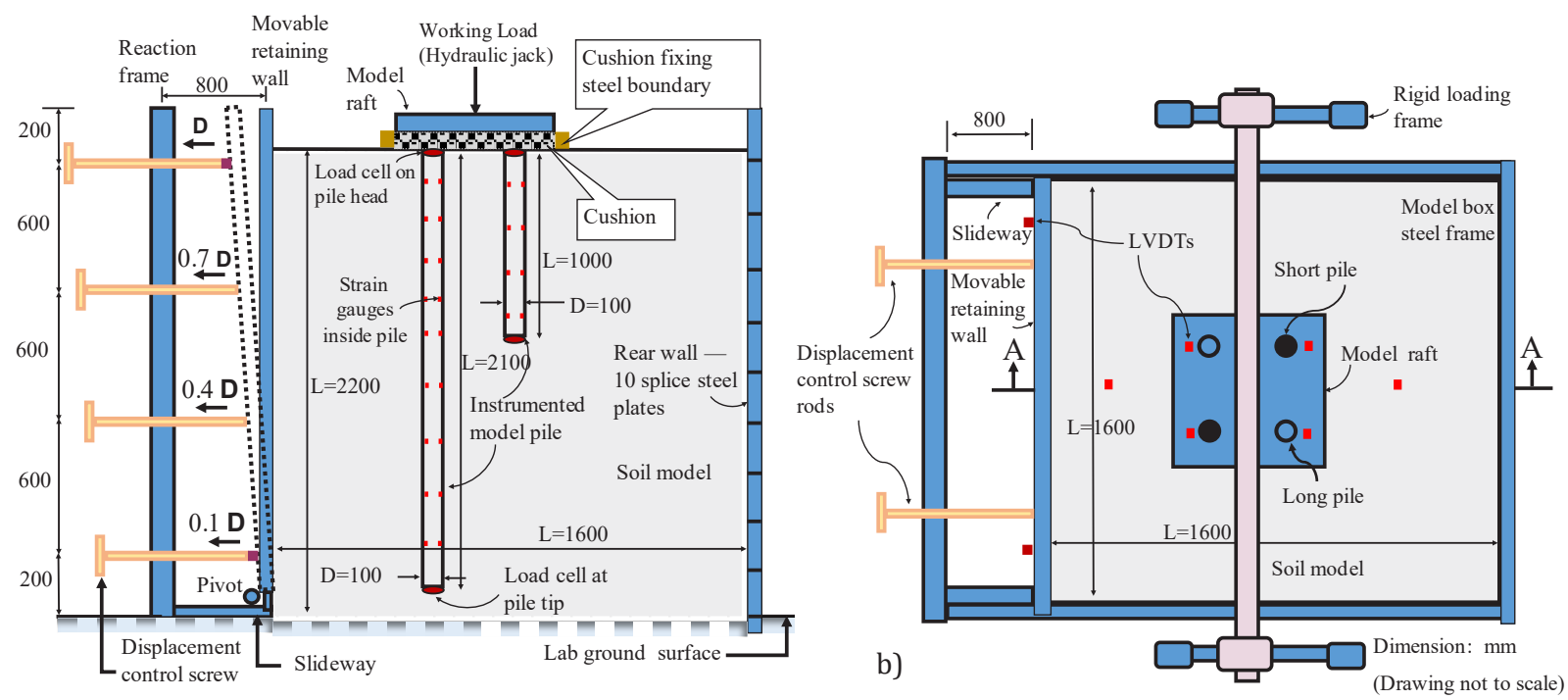

c)

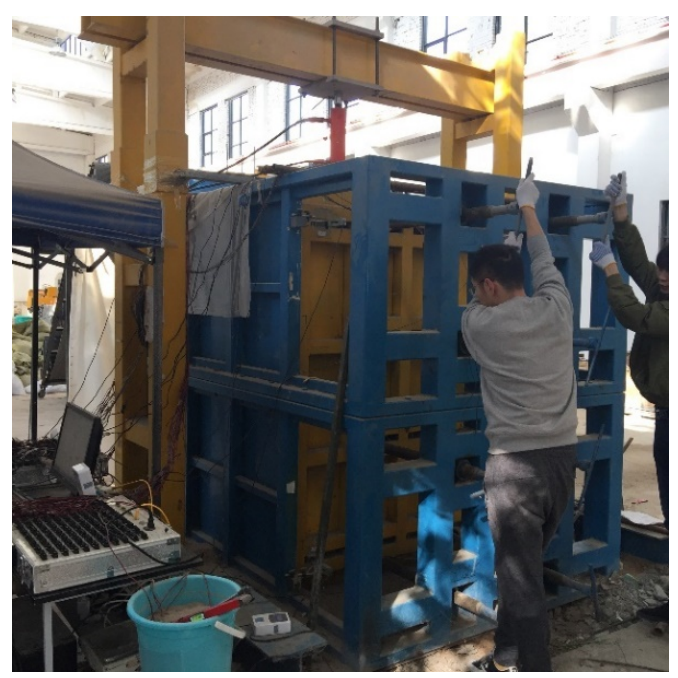

Figure 2: Schematic view of the test model setup: (a) sectional view, (b) plan view and (c) photograph taken during wall rotation.

the interacting interfaces. The face of stiffer contacting part was set as master surface contact candidate, while a slave surface described the other contacting body's surface. Penalty friction formulation was enforced for both tangential and normal behaviours, assuming 0.005 $\mathrm{m}$ limiting displacement for the elastic slip to develop full contact friction, as suggested by Miao et al. ${ }^{[48]}$ to overcome overestimation of pile bending moment.

\subsection{Experimental setup and testing procedure}

The FE model employed in this study was compared with the results from an indoor experiment conducted using a model box of $1.6 \mathrm{~m} \times 1.6 \mathrm{~m} \times 2.5 \mathrm{~m}$ inner dimension, which was sufficient to ignore boundary effects. The apparatus was designed and developed by the Research Institute of Geotechnical Engineering at Zhengzhou University. The model test setup is shown schematically in Figure 2 and was composed of stationary side walls braced with square section RHS fame, movable front wall equipped with bottom roller and slideway, and dismountable 10 splitsteel plates connected to the frame with high-strength bolts forming the rear wall. Displacement control screw rods were symmetrically located at the top, middle and lower levels of the right and left edges of the front wall to permit rotation/translation in a way similar to that used by other researchers such as Yang et al. ${ }^{[49]}$ Rectangular RHS steel reaction frame was positioned beside sidewalls. 
The test was conducted on $2 \times 2$ (two long-two short) pile composite foundation. Instrumented hollow aluminium close-ended tubes of length 2100 and 1000 $\mathrm{mm}$ were used as long and short piles, respectively, considering the length similarity ratio $\left(\lambda_{\mathrm{L}}\right)$ of 3 to account for scale effect. The pile's Young's modulus was $72 \mathrm{GPa}$ and was not emulated for scaling. The outer diameter and thickness of each pile were 100 and $3 \mathrm{~mm}$, respectively. The roughness of pile shaft surface was established with knurling treatment and effectuated an interface angle of friction $27.3^{\circ}$. The spacing of the piles in model and prototype was three times the pile diameter, so that the area replacement ratio remained 0.087 .

A plain carbon structural steel plate (quality Q235B) of dimension $600 \mathrm{~mm} \times 600 \mathrm{~mm} \times 50 \mathrm{~mm}$ was used as a rigid raft according to the stiffness requirement suggested by Horikoshi and Randolph. ${ }^{[50]}$ Fine dry river sand of Zhengzhou city, China and standard sand with the grain size distribution presented in Figure 3 were used as a foundation soil and cushion layer, respectively, according to the test requirement in the Chinese specification (GB/T 50783-2012). The scale effect of particle size on ultimate skin friction was also cross checked, so that the ratio of pile diameter $(\mathrm{d})$ to the average particle size of the soil (D50) was at least 30-50 according to Fioravante's ${ }^{[51]}$ suggestion. The maximum and minimum dry densities of the analogous fine sand were 1.795 and $1.592 \mathrm{~g} / \mathrm{cm}^{3}$, respectively. The cushion layer had a thickness of $50 \mathrm{~mm}$. The bearing layer was prepared by pouring and tamping technique with the sand being freely dropped from the height of the model box by a conveyor belt. Once the fill was made to the level of the prescribed pile toe, the pile was positioned vertically and the next layer was continued to the final surface. After the final sand surface was levelled, soil pressure cells were placed at the specified locations before laying the cushion layer. The cushion layer was placed after the bounding steel frame was laid. Then, the loading plate was stationed on top of the cushion.

The vertical working load was applied using a hydraulic jack pressed against the top beam of the reaction frame, and a load cell was mounted between the jack and the beam. The model ground had then been rested for more than a week before the loading process was begun, in order to balance the stress state of the soil. The loading application was performed according to the Chinese technical specifications for building foundation inspection (JGJ340-2015), technical code for testing of building foundation piles (JGJ106-2014) and technical code for ground treatment of buildings (JGJ 79-2012).

The settlement of raft surface during the loading process was obtained from the reading taken by YHD

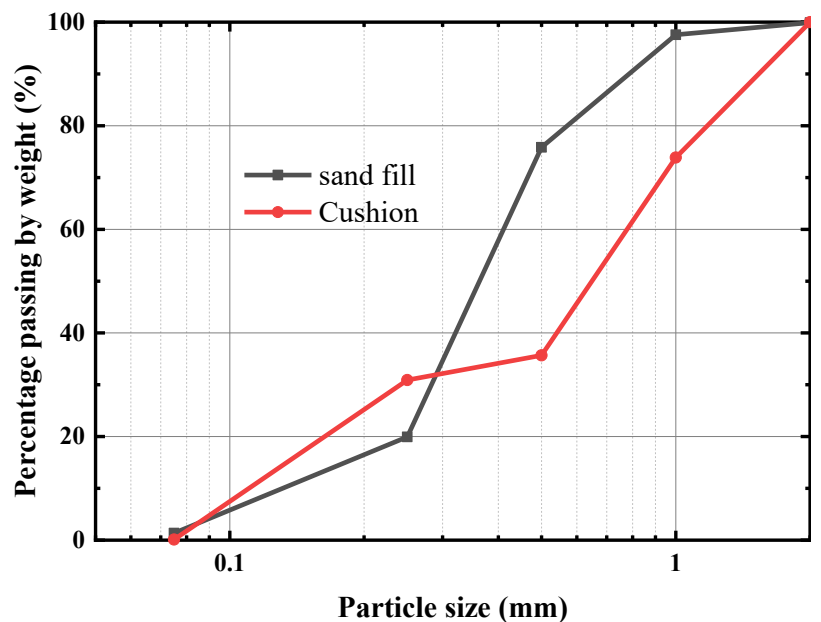

Figure 3: Particle size distribution of cushion and model foundation soil

series electronic strain-type displacement sensors. All the strain gauges attached to the pile body, displacement transducers and pressure sensors placed at the top soil surface between piles and on the head and tip of pile were connected to static digital data acquisition system to collect real-time data. Each earth pressure-measuring cell and load sensor was verified for repeatability through indoor calibration preceding the experiment to correct calibration coefficients and stress hysteresis effect.

Based on existing research works conducted with the same model box, ${ }^{[13,14]}$ the rotation of wall about the base required to attain active limit state resulted in the top of the wall to displace laterally an amount of $\Delta=10-15 \mathrm{~mm}$ ( $0.47 \%-0.75 \%$ of the wall height). Accordingly, this study used 10-mm horizontal movement of the wall top away from the foundation in 11 stages, with $0.5 \mathrm{~mm}$ at the beginning and $1.0 \mathrm{~mm}$ each for the remaining. Consequently, the displacement of the screw rods on the top was controlled manually to obtain 0.5 or $1.0 \mathrm{~mm}$ at each stage, according to the calibration of screw rode rotation to yield the same. After the data of each stage were stable, the next rotation was carried out. Since settlement occurred as wall rotation advanced, for this very reason, the applied load on the foundation was manually sustained to maintain the hydraulic jack pressure unchanged throughout the process.

In order to compare experimental and numerical results with each other, the FEA was performed on the same geometric configuration, but with the depth of the sand being twice the long piles' length. Table 1 summarises the material parameters used to back analyse the experiment, while Figure 4 presents the load settlement before wall rotation and the load-sharing characteristics 


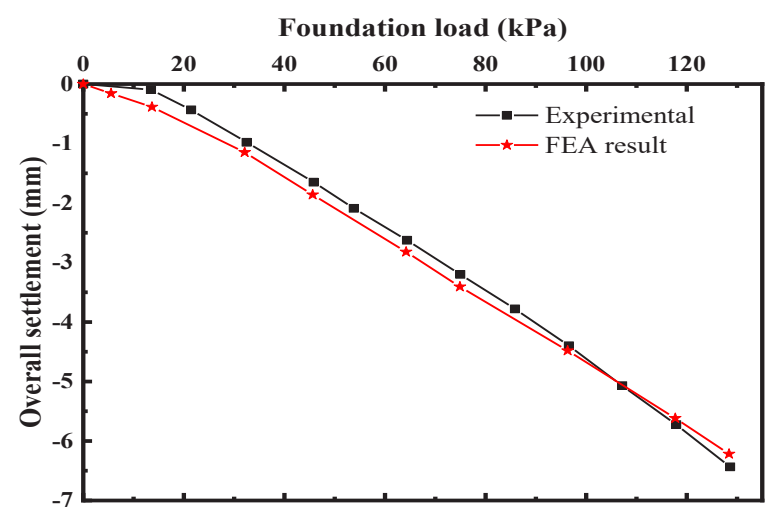

b)

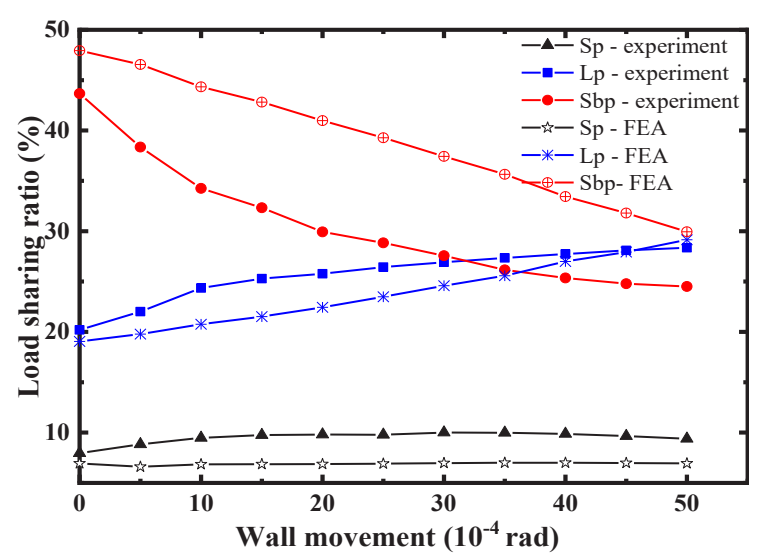

Figure 4: Comparison of experimental (a) load settlement curve and (b) load-sharing ratio during wall rotation with finite element analysis result (Lp - long pile, Sp - short pile, Sbp - soil between piles).

Table 1: Material properties used in validation.

\begin{tabular}{llllll}
\hline Material type & $\begin{array}{l}\mathrm{E} \\
(\mathrm{MPa})\end{array}$ & $\mathbf{v}$ & $\begin{array}{l}\mathrm{V}(\mathrm{kg} / \\
\left.\mathrm{m}^{3}\right)\end{array}$ & $\begin{array}{l}\boldsymbol{\Phi} \\
\left({ }^{\circ}\right)\end{array}$ & $\begin{array}{l}\mathbf{C} \\
(\mathrm{kPa})\end{array}$ \\
\hline Cushion & 15.00 & 0.30 & 1416 & 33.90 & 4.00 \\
Soil & 10.50 & 0.30 & 1618 & 33.42 & 6.48 \\
Pile & $8.14 \times 10^{3}$ & 0.20 & 2700 & - & - \\
Raft & $210 \times 10^{3}$ & 0.20 & 7800 & - & - \\
Retaining wall & $210 \times 10^{3}$ & 0.10 & 7800 & - & - \\
\hline
\end{tabular}

during wall rotation. It can be seen that the prediction from the numerical simulation was in agreement with the results from the experiment in terms of magnitude and trend. Thus, the behaviour of long-short pile composite foundation can reasonably be predicted following similar numerical simulation procedure for succeeding analyses.

\section{Stress path analysis}

It is common to represent the complex state of soil stress during excavation using stress paths plotted on $p-q$ plane. The $p-q$ plane is nothing, but a plot of the mean isotropic (hydrostatic) stress vs. deviatoric (shapechanging) stress. Since the pile-to-pile spacing in CFG pile composite foundation usually ranges from 2 to 5 times the pile diameter (d) and the outward projection of the mat edge from the outer pile is 1.5-2 times of the pile diameter, ${ }^{[52]}$ this study used a pile spacing of $3 \mathrm{~d}$ (i.e., $3 \times 0.4 \mathrm{~m}$ ) with the raft projected by $2 \mathrm{~d}$ (i.e., $0.8 \mathrm{~m}$ ) from the centre of peripheral piles. An upper vertical pressure of $180 \mathrm{kPa}$ was imposed on the top surface of the raft as a working foundation load. The initial stress state of the foundation was considered as a stress state condition under the applied vertical load, expressed as state ' 0 ' in further discussions unless otherwise stated. 


\subsection{Soil stress path mobilised at different locations}

The changes in the state of stress during the process of wall movement were examined with the mobilised stress path of the soil elements at different selected monitoring points. As depicted in Figure 5, the stress path for each observation point travelled downwards towards the $K_{f}$ -line (except for point B), indicating a reduction in both lateral and vertical stresses during the subsequent wall movement. It is well known from the basic soil mechanics that with increase in the depth, the vertical stress of the soil mass increases. Subsequently, the stress state on the $p-q$ plane for the soil element at the observation point A was much lower than that of the soil element at point $B$. The same was true for the upper soil elements $C$ and $E$, as compared to their respective bottom points $\mathrm{D}$ and $\mathrm{F}$.

The behaviour of the stress path for point $\mathrm{B}$ in this analysis was seen to be different from others, which might have occurred as a result of the reaction stresses developing at the base of the wall. Accordingly, during advancement of the wall movement, a pattern of mean isotropic stress increment and decrease in deviatoric stress was seen until the completion of wall rotation.

When the stress change in observation point $\mathrm{E}$ was compared to that of $\mathrm{C}$, its stress state underwent a complex path in the earlier stages of wall rotation. It increased first, but reverted back to follow almost the same trend with that of observation point $\mathrm{C}$ after a certain rotation in the later stages of wall rotation. The reason for this behaviour could be the shadowing and reinforcing effect of the front pile, so as in the earlier stage of wall rotation, the incidence of gap formation between the cushion and soil due to the wall movement reduced the stress borne by soil element $\mathrm{C}$ and the corresponding stress was transferred to the neighbouring stiffer material. This increased the stress received by the soil between piles. As the wall progression continued, the soil element $\mathrm{E}$ underwent a stress relief and followed the stress path trace of point $\mathrm{C}$.

\subsection{Principal stress rotation}

Generally, it is difficult to totally avoid excavation-induced soil displacements in which the soil elements migrate towards the pit along with the inward retaining wall movement. Such a phenomenon generates a change in the stress state in conjunction with principal stress axes' rotation. ${ }^{[3,40,53]}$ As the wall movement in the current study altered the initial stress state of the soil, variations of the stresses during the process brought changes not only in

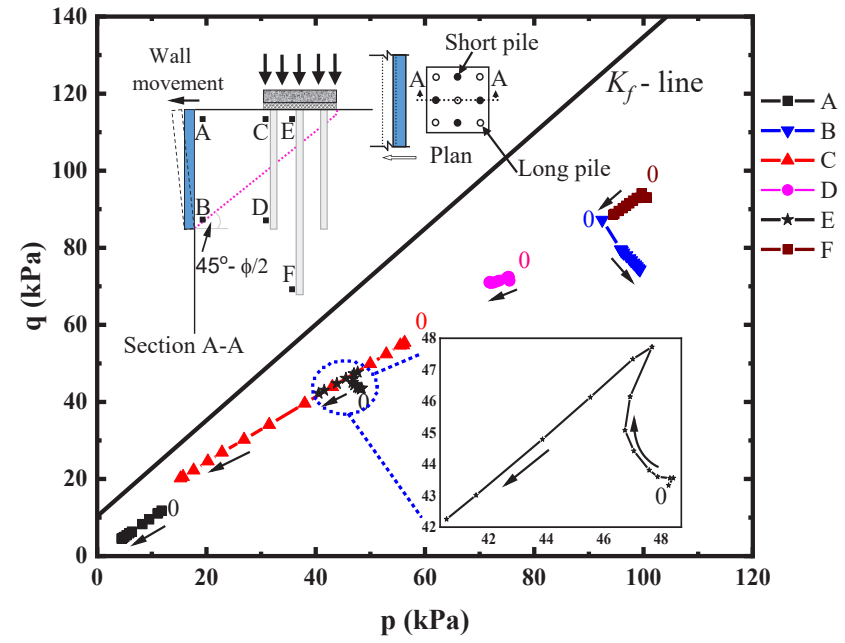

Figure 5: Soil stress paths at different observation points for nine long-short pile composite foundation located at $3 \mathrm{~m}$ away from the wall ( 0 indicates the stress state before wall rotation)

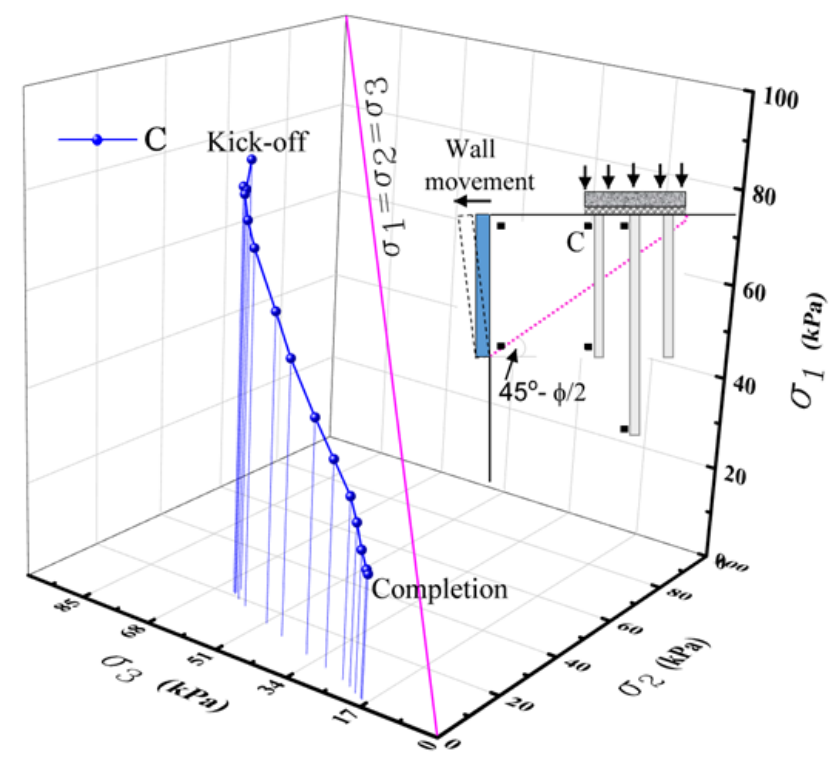

Figure 6: Principal stress changes during wall rotation about the base for nine long-short pile composite foundation located at $3 \mathrm{~m}$ away from the wall.

the magnitude, but also in the direction of the principal stresses. Figure 6 presents the stress change evolution schematically on a 3D stress space of principal axes $\sigma_{1}, \sigma_{2}$ and $\sigma_{3}$. The observation stress point $C$ was taken for a soil element adjacent to the composite foundation at a distance $3 \mathrm{~m}$ behind the wall. It is obvious from the stress path illustration that from the kick-off to completion of wall movement, the soil element underwent stress unloading owing to a drop in the percentage of vertical load sharing of the soil and reduction of lateral confinement as a 

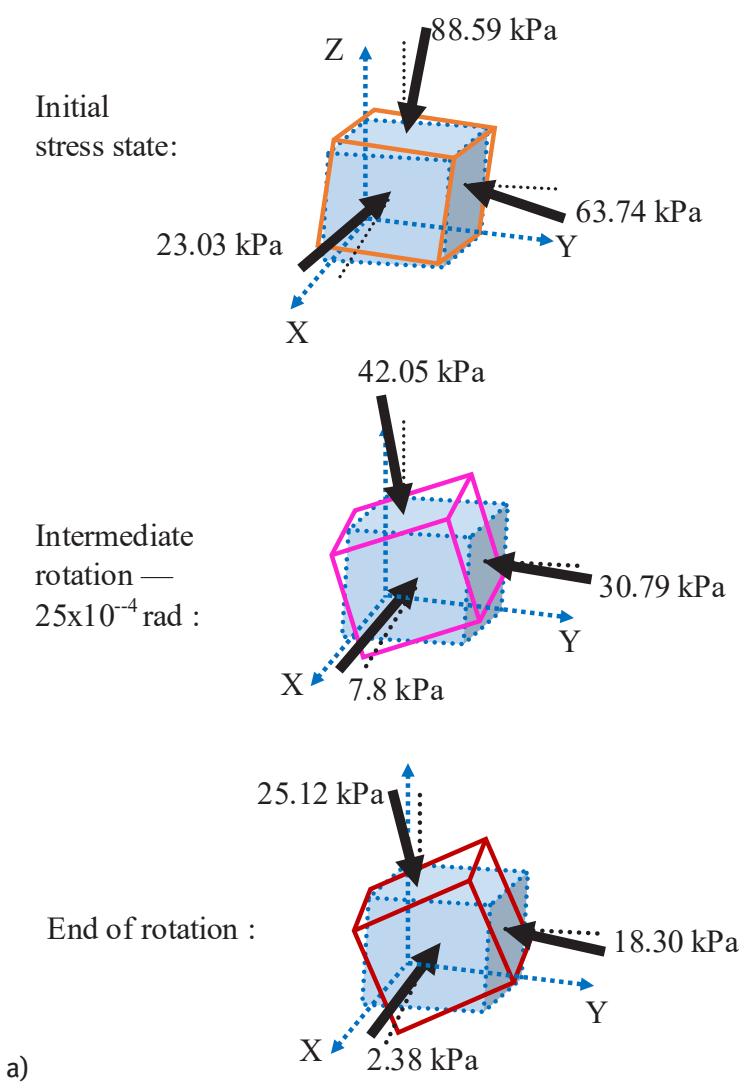

a)

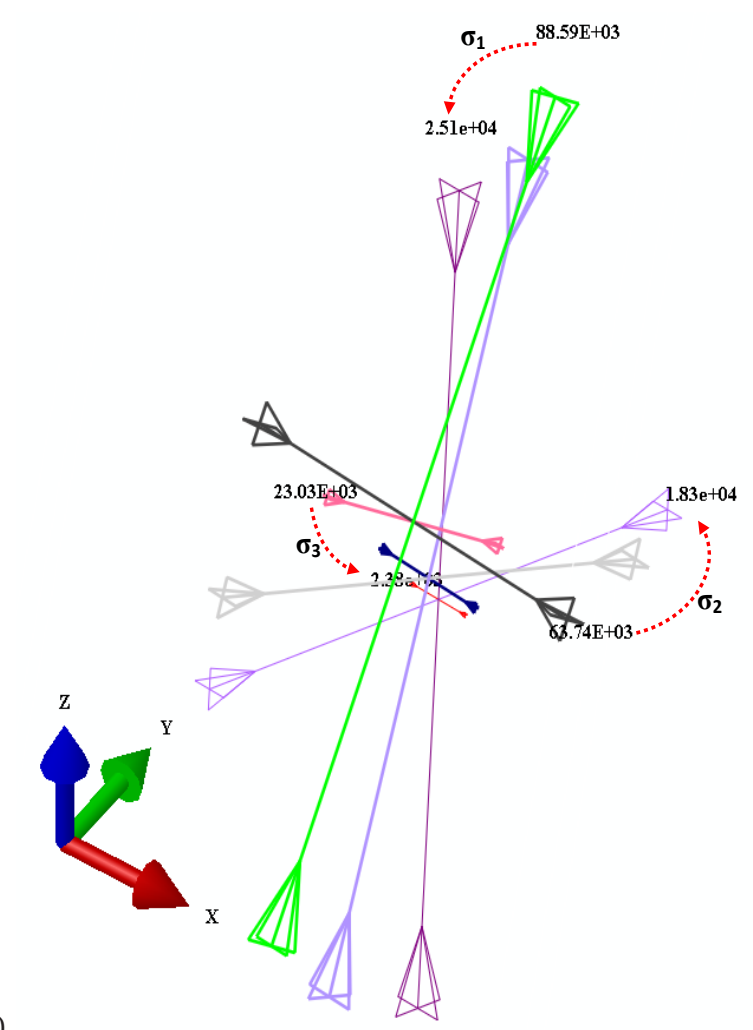

b)

Figure 7: PSRs of element C: (a) 3D cubical element representation and (b) symbol plot for nine long-short pile composite foundation located at a distance $3 \mathrm{~m}$ away from the wall result of wall movement-induced stress relief. This stress reduction occurrence was also associated with changes in the direction of the principal stresses, as can be seen from the projection on the $\sigma_{2}-\sigma_{3}$ plane. An excerpt on the stress state in terms of principal stress magnitude and orientation for the same soil element is given in Figure 7.

The 3D principal stress directions can easily be obtained using programs such as MATLAB without doing algebra to calculate the eigenvectors. It is to be reminded that during PSRs, direction changes alone can produce plastic deformations. So as to have safer designs, deformations associated with PSR should not be neglected, apart from change in principal stress magnitude. ${ }^{[54]}$ Accordingly, a constitutive relationship that could possibly capture the plastic deformations to a better accuracy is sought for a higher fidelity, which mostly exists as sophisticated and overly complex advanced models, rendering practical difficulty for model parameter characterisation. Nonetheless, previous studies have shown that irrespective of the type of model employed, fairly accurate excavation-engendered stress change behaviour can be obtained. ${ }^{[38,40,46]}$

\subsection{Effect of location of the composite foundation from the wall}

Figure 8 shows the effect of distance from the wall on the change of stress experienced by the soil element C. As can be seen from the illustration, the influence of wall rotation on relocation of the stress and interplay between the soil and pile becomes less significant, but is still accompanied by similar trend on the $p-q$ plane as the distance from the wall is increased. That is, if the CFG composite foundation is located closer to the wall, the foundation soil element just near the top of the first raw of piles experiences a stress path in which $q$ decreases due to confining stress relief and $p$ reduces owing to the bearing capacity drop in the upper ground because of wall rotation-induced soil settlement. In the case of composite ground situated relatively far away from the wall, the monitoring point experiences a stress path with little disturbance from the lateral unloading and settlement effect of an adjacent retaining wall rotation.

Observation on the change of load-sharing proportion of the soil (e.g., see Figure 4b) during the process of wall movement indicated that the percentage in bearing capacity of the soil between piles for the composite foundation situated at $3 \mathrm{~m}$ distance away from the wall reduced from $67.03 \%$ to $59.52 \%$, while the reduction for those placed at 5, 7.5 and $10 \mathrm{~m}$ was from $65.23 \%$ to $60.45 \%$, 


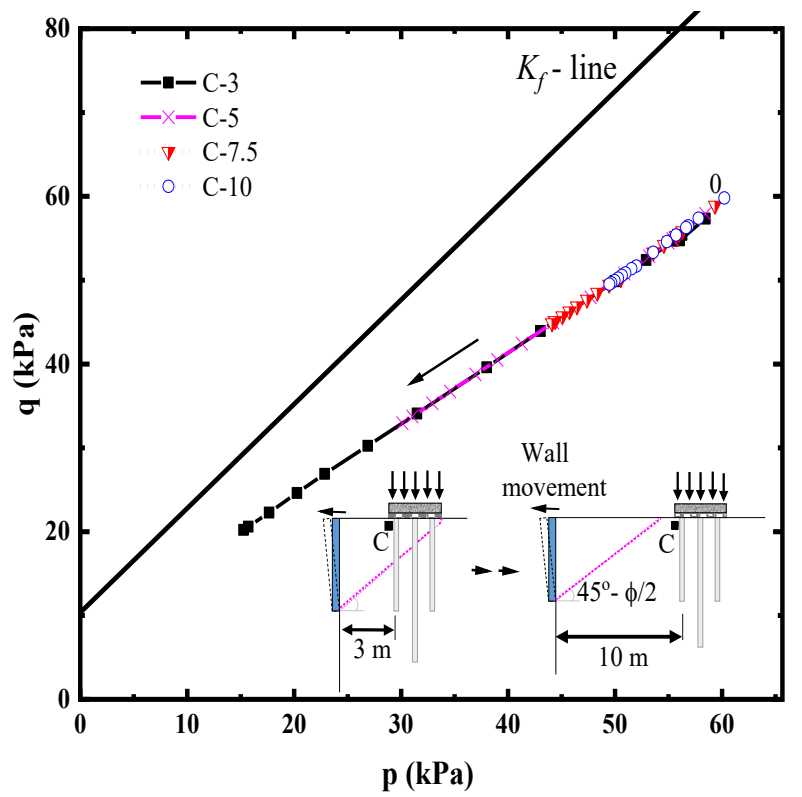

Figure 8: Stress paths experienced by a soil element for different locations of the composite foundation from the wall.

$65.47 \%$ to $62.63 \%$ and $65.74 \%$ to $63.53 \%$, respectively. As the distance from the wall is increased, the effect of wall movement disturbance on the load-sharing proportion of the reinforced ground gradually diminishes. As the main intention of composite foundation is to bring the soil between piles to participate in sharing a certain amount of the applied foundation load, the influence of wall movement-induced disturbance should be carefully analysed to maintain the integrity and stability of existing on service CFG pile composite foundation located in close proximity to the wall.

\subsection{Effect of number of piles in the composite foundation}

Figure 9 shows a comparison of the change of stress states in a soil element $\mathrm{C}$ for the composite foundations with different number of piles throughout the whole model simulation process. As it is well understood from the vertical load-carrying characteristics of CFG pile composite foundation, the percentage vertical load borne by the soil between piles decreases as the number of piles increases. ${ }^{[43,55,56]}$ In line with this, the stress invariants for the monitoring element in the composite foundation with 25 piles were smaller than that of the group with nine piles. Accordingly, as shown in Figure 9, the mean isotropic state of stress for the stress element $\mathrm{C}$ on the $p-q$ plane for the group with nine piles was higher for the applied working

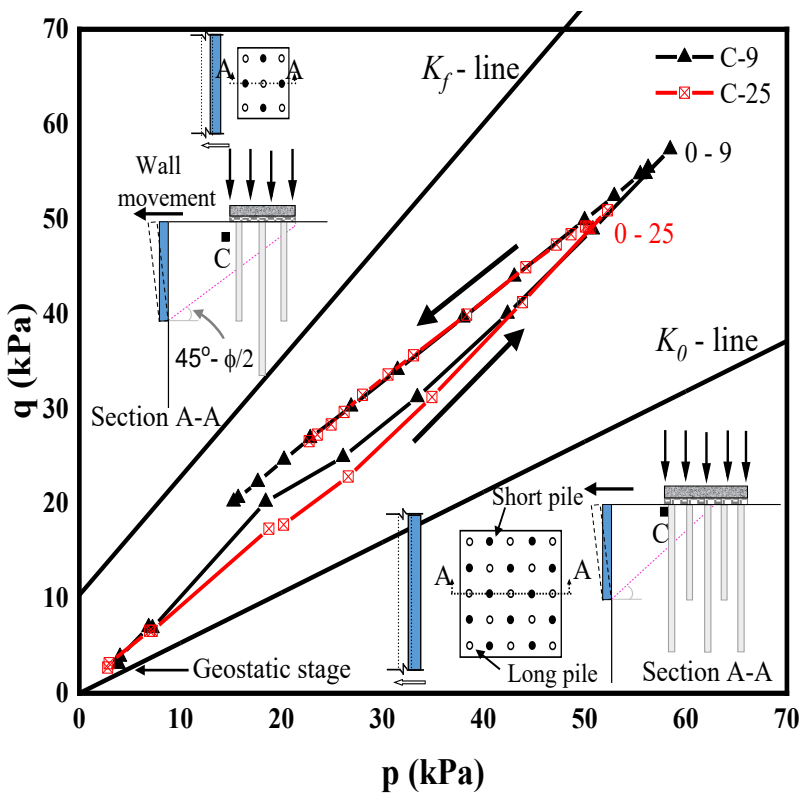

Figure 9: Stress paths experienced by a soil element $C$ for groups with 9 and 25 long-short CFG piles situated at $3 \mathrm{~m}$ behind the wall (C-9 indicates element $\mathrm{C}$ in a group with nine piles)

load. At a first glance, it is noticeable that the stress invariants decrease in both cases with identical stress paths directed downwards during the progression of the wall, but the state of stress at the end of wall movement for the smaller pile groups is much smaller.

Nevertheless, commensurate with dependency of pile responses on the position in the group and the shaft load it transfers to the surrounding soil, the change in stress state for soil elements at $\mathrm{C}$ and $\mathrm{E}$ at the outer and middle elements, respectively, during the advancement of wall rotation differs. Figure 10 gives a comparison of the change of stress in a soil element at the middle section of the composite foundation with different number of piles. It obviously shows that the state of stress at the beginning of the wall rotation is somehow disturbed, but manifests itself differently in each case.

For the group with nine piles, the stress reduction in the beginning stage of wall movement reverted back to increase as the wall movement proceeded to an amount of $25 \times 10^{-4} \mathrm{rad}$, in order to adjust the effect of soil movement. However, as the wall movement proceeded further, the slip surface continued to enclose the stress point, which led to subsequent unloading. On the contrary, due to shadowing and reinforcing effect as well as depending on how far the location of the stress point under consideration was away from the wall, the stress state of the observation point kept increasing throughout the process. The rate of increase in mean isotropic stress and the deviatoric stress 


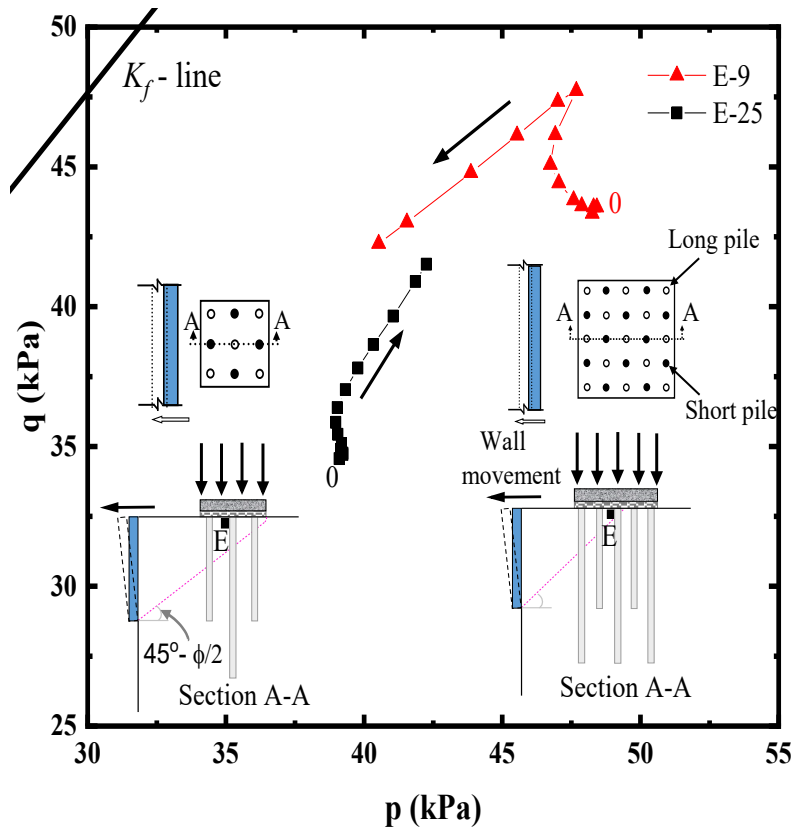

Figure 10: Stress paths experienced by soil element at the central composite foundation section for groups with 9 and 25 long-short CFG piles situated at $3 \mathrm{~m}$ behind the wall.

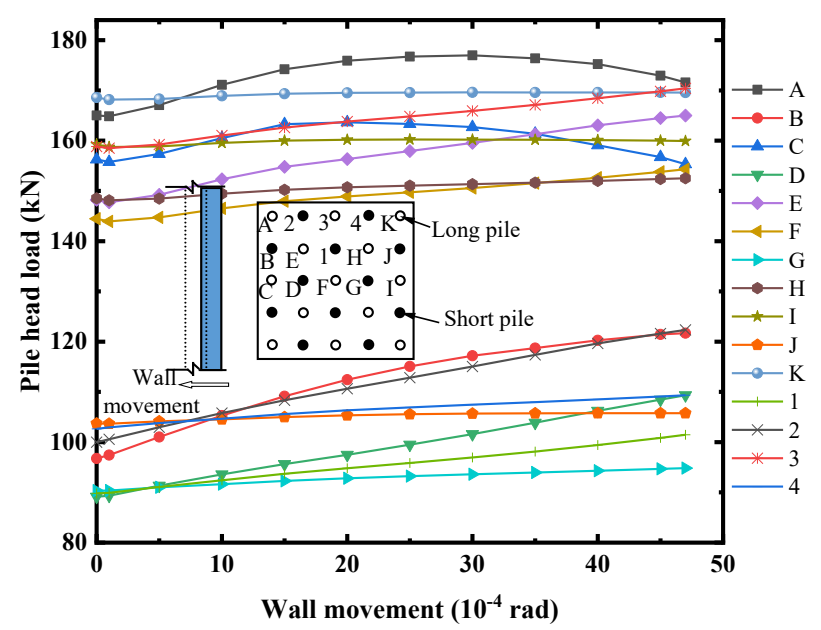

Figure 11: Effect of wall rotation on pile head load in $5 \times 5$ long-short pile group located at $3 \mathrm{~m}$ away from the wall.

increased as the wall movement increased. Even though the upper load received by the soil decreased, the lateral stress of the soil increased as the load being transferred to the front piles redistributed to the inner piles and was further distributed to the surrounding soil. This feature can also be observed from the variation of the pile head load depicted in Figure 11.

It is also worthy to note from Figure 11 that before commencing wall rotation, the corner pile had carried the highest pile head load compared to the central (or inner) pile(s), akin to other previous studies. ${ }^{[10,45,57]}$ As the wall movement advanced, the change in the pile head load depended on the particular position of piles in the group. In other words, the pile-soil interaction and load-carrying mechanism of internal (central), lateral (edge) and corner piles were influenced by the overlap zones of shearing resistance; this mechanical behaviour has also garnered the attention to use dissimilar piles for practical purposes of reducing differential settlement in connected pile rafts. ${ }^{[58-60]}$ In the composite foundation with 25 long and short piles, the percentage of load sharing of the soil dropped from $56.54 \%$ to $53.16 \%$, indicating that the bearing capacity loss of the soil is attributable to wall rotation, which is transmitted proportionally to the piles.

\subsection{Influence of subsoil stiffness}

It is well known in soil mechanics that proper description of the settlement and volume change characteristics of a soil under a certain stress condition depends on the capability to portray the soil's non-linear behaviour and stiffness decay in low strain range. It is also common to capture the distortion component of the soil compressibility (settlement) using Hooke's law employing the tangent modulus. ${ }^{[6]]}$ Accordingly, many scholars used the compression modulus of the soil to estimate the settlement and deformation behaviour of CFG pile composite ground..$^{[62-64]}$

On the other hand, the soil displacement field during excavation is influenced by the stiffness of the retained soil. ${ }^{[65]}$ Both vertical deformation and lateral deformation of the natural ground are affected by the stiffness of the soil, which in turn depends on the stress level. Consequently, the necessity of considering the unloading strength of soil in excavation-induced deformation analysis is frequently discussed by scholars and the proposal to employ it during analysis is highly encouraged due to the fact that failure could occur under small strain as the retaining wall deflects. ${ }^{[39,66]}$ To better understand the initial stress condition change for various stiffness during such unloading instances arising from engineering operations, the stress path followed under different elastic modulus of the analogous soil was compared for the monitoring point $\mathrm{C}$, as depicted in Figure 12.

It is evident from Figure 12 that the smaller the elastic modulus of the soil, the smaller are the stress invariants, as the piles share much of the applied pressure. This encourages the soil to share smaller proportion of the imposed load which gets little disturbance. Whereas for 


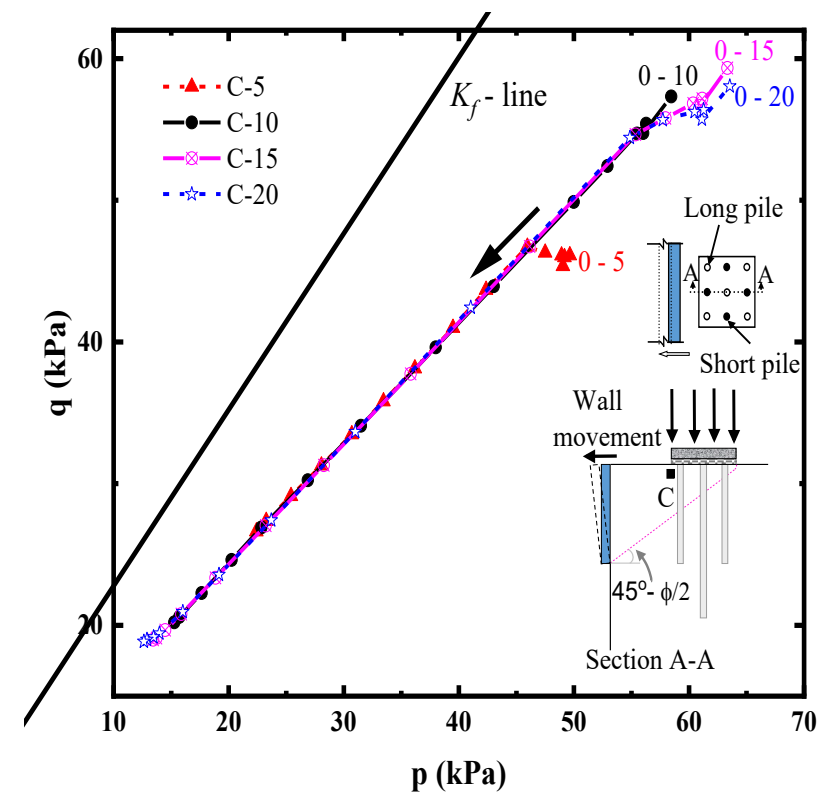

Figure 12: Influence of soil stiffness on the stress state during wall progression (e.g., 0-5 indicates initial stress state before wall movement for the case $\mathrm{E}=5 \mathrm{MPa}$ ).

the piles embedded in a soil of higher stiffness, the upper soil proportionally bears higher load and the disturbance from the wall movement relatively affects the stress state of the soil largely during the progression of the wall movement. This is because of the reduction of the soil stress received beneath the cushion due to the soil displacement occurring as the wall movement proceeds.

\subsection{Influence of the area replacement ratio and working load}

Several researchers have discussed about the effect of cover ratio on the settlement and load-sharing characteristic of composite pile foundation under vertical loading in which the area replacement ratio was varied by either changing the pile diameter (or its head) $)^{[45,56,67]}$ or by provision of pile cap. ${ }^{[68,69]}$ The analyses in the current study reveal that keeping the intensity of the imposed raft load the same, but allowing the cover area ratio of the piles to increase by reducing the spacing of pile makes the stress path in a group with nine piles to follow a similar trend to what is portrayed in Figure 5, but with lower soil stress at smaller pile spacing. This feature is not reproduced and depicted here again to avoid redundancy and for space brevity. The behaviour of smaller percentage of load shared by the soil as the clearance between the piles decreases is a well-known mechanical behaviour of CFG pile composite foundation. Provoking wall rotation only decreases the stress invariants, keeping the trend almost similar, in an attempt to equilibrate the soil stress release from imposed soil movement. The relative higher stiffness of the piles with respect to the soil dictates more load to be drawn to the piles as the elastic modulus of the soil decreases. The result of the analysis showed that for the replacement ratios of 3.14, 4.91 and $8.73 \%$, the overall upper soil loadbearing proportion lowered from $45.25 \%$ to $37.17 \%, 55.32 \%$ to $47.83 \%$ and $67.02 \%$ to $59.52 \%$, respectively, due to the effect of wall movement. Similarly, when the working load was changed while the pile area cover ratio was kept constant, the trend of the stress path experienced by the soil elements under consideration followed almost similar trace as that of Figure 5, but with a higher state of stress due to increases in stress invariants. The pattern is also not repeated here to avoid redundancy of similar behaviours. However, it is worth noting that with increased working load, the load carried by the pile increases and the percentage proportion shared by the soil decreases.

\subsection{Response of soil element beneath pile toe}

When it comes to monitoring the points taken underneath the tip of the pile, the stress path ascends with wall movement progression unlike those stress points in the upper part close to the shaft. This is demonstrated in Figure 13. As each pile carries different amount of vertical load depending on the location of the pile in the group (refer also Figure 11), they transmit different amounts of stress to their surrounding soil layer. It can be observed that the amount of stress increase appearing on the stress state for the soil element underneath the piles in the first and second pile raw differed depending on the length of the piles. It was larger below the long pile in the second raw as compared to that felt by the soil element beneath the long pile in the first raw, but was vice versa for the soil elements below short piles.

\subsection{Variation of the induced deviatoric stress with volumetric strain}

The load deformation characteristics can also be articulated in terms of change in volumetric strain $\varepsilon_{v}$ expressed against the corresponding deviatoric stress tensor $\mathrm{VJ}_{2}$ on soil specimens tested under different stress paths.

Figure 14 portrays the shear stress $\mathrm{VJ}_{2}$ - volumetric strain $\varepsilon_{v}$ variations as the wall movement proceeded for 


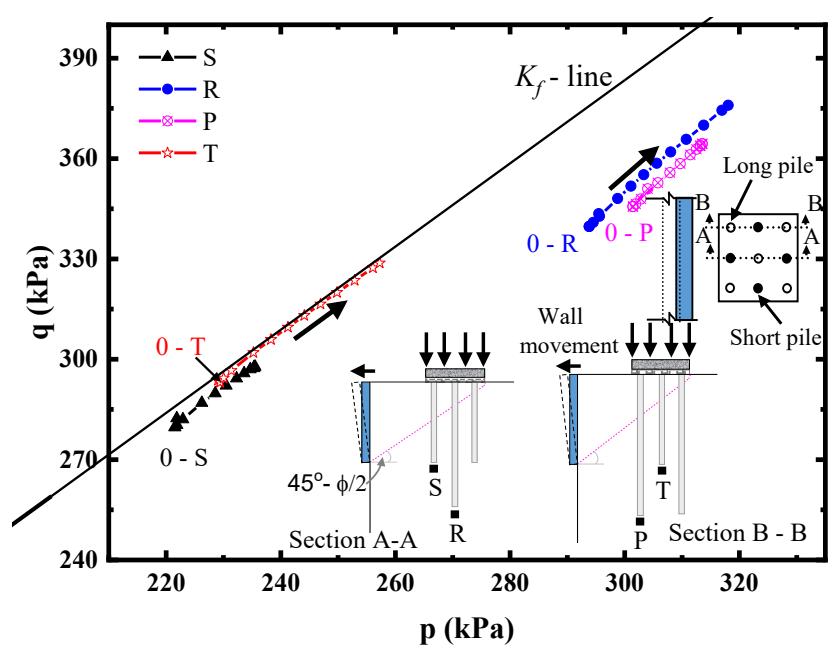

Figure 13: Response of soil element beneath the pile toe during wall movement (e.g., 0-S indicates initial stress state before wall movement for element S).
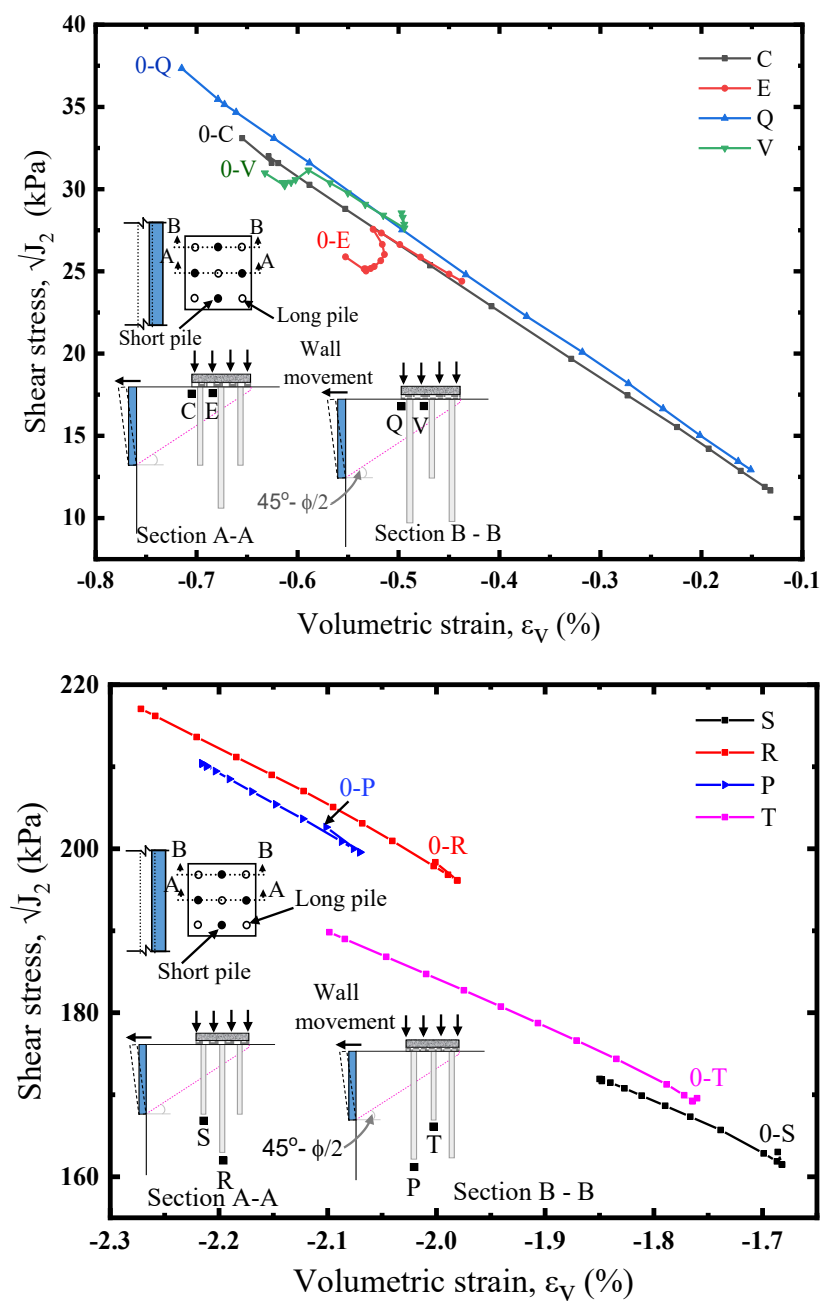

Figure 14: Computed shear stress-volumetric strain curves for monitoring points (a) in the upper soil near pile shaft and (b) underneath pile toe. soil elements surrounding the upper pile section and below the pile tip of the composite foundation located at $3 \mathrm{~m}$ away from the wall. It indicates that the volume change behaviour within the treated ground depends on the location of the soil element under consideration. The demonstration suggests that the state of stress at each wall rotation stage impacts the deformation pattern of the soil. Intuitively, it could be anticipated to find larger stain in the X-axis (direction normal to the wall) near the top section. So is the strains increment in the other directions, but not as large as the strain in the X-axis. The combined effect of these strains determines the dilation behaviour of the soil upon loading and unloading; in fact, reasonably accurate real behaviour could judiciously be found implementing sophisticated constitutive models that are capable of reflecting the non-linear soil responses. The stress relief and redistribution among the piles are more pronounced within the influence range around the wall.

\section{Conclusions}

Understanding the stress path followed during excavations is propitious to successfully capture engineeringimpinged disturbances on pre-existing state of stress and their associated ground deformation during both design and construction stages with application of observational method. To add insights in this regard, this paper numerically investigates the stress path experienced in composite ground reinforced with long and short rigid pile inclusion as adjacent retaining wall movement proceeds. From the results, we obtain the following conclusions:

- As the wall movement advances, it produces ground displacement behind the wall. The disturbance it brings to the soil in the vicinity manifests a process of lateral and vertical stress unloading. As the upper soil is loaded by a certain proportion of the working load, the wall movement-induced settlement reduces the pre-existing stress borne by the soil and the corresponding stress will be carried by the piles. The stress path during progression of wall movement is affected by how the test points are positioned and enclosed by the piles in the composite foundation. Peripheral elements that are close to the wall experience larger stress unloading. Interior stress points behave differently depending on the number of piles and the proximity to the theoretical slip surface.

- The stress path for the upper soil around the pile shaft and facing the wall moved down towards the $K_{f}$-line owing to the reduction of the stress invariants, which 
is accompanied by rotation of the principal stresses. The stress relief is felt lesser when the points are located far from the wall. For the points underneath the tip of each pile, however, the stress path moves upwards due to increment of both the mean isotropic and deviatoric stresses.

- At least for the current boundary condition, the consequence of wall movement progression on the stress release felt by the soil just below the long and short piles is different. The soil stress increment for the soil element beneath the short pile near the wall (first raw) is smaller than that underneath the short pile in the second raw. For the long piles, it undergoes the other way around, indicating the load transfer to the pile end during progression of wall rotation occurs at different load redistribution amount.

- The disturbance of wall movement on the vertical preexisting load-sharing state of the soil is minimal when (1) the composite foundation has larger number of piles and/or has larger area replacement ratio, (2) the composite foundation is placed relatively far from the wall, (3) the natural ground has lower stiffness and (4) the imposed working load is smaller.

Acknowledgement: This work was supported by the National Natural Science Foundation of China under Grant 51508522.

\section{References}

[1] Poulos, H. G. (2016). Tall building foundations: Design methods and applications. Innovative Infrastructure Solutions, 1(1), 10. https://doi.org/10.1007/s41062-016-0010-2

[2] Uge, B. U., \& Guo, Y.-C. (2020). CFG Pile Composite Foundation: Its Engineering Applications and Research Advances. Journal of Engineering, 2020, 1-26. https://doi. org $/ 10.1155 / 2020 / 5343472$

[3] Halder, P., \& Manna, B. (2021). Large scale model testing to investigate the influence of granular cushion layer on the performance of disconnected piled raft system. Acta Geotechnica. https://doi.org/10.1007/s11440-020-01121-5

[4] Rui, R., Han, J., Ye, Y., Chen, C., \& Zhai, Y. (2020). Load Transfer Mechanisms of Granular Cushion between Column Foundation and Rigid Raft. International Journal of Geomechanics, 20(1), 04019139. https://doi.org/10.1061/(ASCE)GM.19435622.0001539

[5] Jiang, W., \& Liu, Y. (2018). Determination of neutral plane depth and pile-soil stress ratio of the rigid pile composite foundation. Rock and Soil Mechanics, 39(12), 4554-4560. https://doi. org/10.16285/j.rsm.2017.0812

[6] Tradigo, F., Pisanò, F., \& di Prisco, C. (2016). On the use of embedded pile elements for the numerical analysis of disconnected piled rafts. Computers and Geotechnics, 72, 89-99. https://doi.org/10.1016/j.compgeo.2015.11.005

[7] Wu, C., Guo, W., \& Li, Y. (2016). Calculation of neutral surface depth and pile-soil stress ratio of rigid pile composite foundation considering influence of negative friction. Chinese Journal of Geotechnical Engineering, 38(2), 278-287. https:// doi.org/10.11779/CJGE201602011

[8] Yan, F., \& Huang, X. (2014). Experiment Research of Bearing Behavior on Lime-Soil Pile and CFG Pile Rigid-Flexible Pile Composite Subgrade. Ground Improvement and Geosynthetics, 40-48. https://doi.org/10.1061/9780784413401.004

[9] Zhang, E., Yu, L., \& He, X. (2016). Analysis of Action Mechanism for Rigid Flexible Pile Composite Foundation. Revista Tecnica De La Facultad De Ingenieria Universidad Del Zulia, 39(11), 260-270. https://doi.org/10.21311/001.39.11.32

[10] Guo, Y. C., Zhang, S. H., Shi, G., \& Liu, N. (2011). Optimization Strategy of the Long-Short-Pile Composite Foundation Based on the Settlement Control. Advanced Materials Research, 243-249, 2429-2434. https://doi.org/10.4028/www.scientific. net/AMR.243-249.2429

[11] Lu, H., Gao, Q., Zhou, B., Wang, D., \& Liang, M. (2015). Experimental Research on Bearing Capacity of Long-and-short Pile Composite Foundation. Chinese Journal of Underground Space and Engineering, 11, 56-63.

[12] Li, L., Zhang, H., Xu, B., \& Wang, Y. (2012). Optimization of excavation supporting structure considering lateral reinforcement effect of CFG composite foundation on soils. Chinese Journal of Geotechnical Engineering, 34, 500-506.

[13] Wei, Y. (2018). Research on evolutionary mechanisms and calculation method of earth pressure against rigid retaining walls close to rigid composite foundation [PhD Dissertation]. Zhengzhou University.

[14] Li, M., Qian, Y., Guo, Y., Wei, Y., Zhao, S., \& Cui, X. (2019). Design of lateral soil pressure model test scheme for adjacent composite foundation. Mechanics in Engineering, 41(2), 157-163. https://doi.org/10.6052/1000-0879-18-418

[15] Li, L., Huang, J., \& Han, B. (2018). Centrifugal Investigation of Excavation Adjacent to Existing Composite Foundation. Journal of Performance of Constructed Facilities, 32(4), 04018044. https://doi.org/10.1061/(ASCE)CF.1943-5509.0001188

[16] Ji, Q. X., \& Ge, X. S. (2013). The Research on the Influence of the Forms of Foundation on the Behavior of Adjacent Excavation Based on Building Materials. Advanced Materials Research, 788, 606-610. https://doi.org/10.4028/www.scientific.net/ AMR.788.606

[17] Li, L., Huang, J., \& Ji, X. (2019). Lateral pressures on retaining wall of composite foundation in clayey soils. Chinese Journal of Geotechnical Engineering, 41(1), 89-92. https://doi. org/10.11779/CJGE2019S1023

[18] Wang, G., \& Yang, Y. (2013). Effect of cantilever soldier pile foundation excavation closing to an existing composite foundation. Journal of Central South University, 20(5), 13841396. https://doi.org/10.1007/s11771-013-1626-4

[19] Fu, Q., \& Li, L. (2021). Vertical Load Transfer Behavior of Composite Foundation and Its Responses to Adjacent Excavation: Centrifuge Model Test. Geotechnical Testing Journal, 44(1), 20180237. https://doi.org/10.1520/GTJ20180237

[20] Uba Uge, B., \& Guo, Y. (2020). Deep Foundation Pit Excavations Adjacent to Disconnected Piled Rafts: A Review on Risk Control 
Practice. Open Journal of Civil Engineering, 10(03), 270-300. https://doi.org/10.4236/ojce.2020.103023

[21] Li, M., Qian, Y., Guo, Y., \& Wei, Y. (2019). Study on Influence of retaining wall rotation on load distribution of rigid - pile composite foundation. Journal of Shenyang Jianzhu University ( Natural Science), 35(4), 655-662.

[22] Korff, M., Mair, R. J., \& Van Tol, F. A. F. (2016). Pile-Soil Interaction and Settlement Effects Induced by Deep Excavations. Journal of Geotechnical and Geoenvironmental Engineering, 142(8), 04016034. https://doi.org/10.1061/ (ASCE)GT.1943-5606.0001434

[23] Li, M., \& Zhao, J. (2018). Progress of Research Advance on the Model Tests on the Interaction Between New Constructions and Adjacent Existing Buildings. In D. Zhang \& X. Huang (Eds.), Proceedings of GeoShanghai 2018 International Conference: Tunnelling and Underground Construction (pp. 536-547). Springer Singapore. https://doi.org/10.1007/978-981-13-00172_54

[24] Mu, L., Chen, W., Huang, M., \& Lu, Q. (2020). Hybrid Method for Predicting the Response of a Pile-Raft Foundation to Adjacent Braced Excavation. International Journal of Geomechanics, 20(4), 04020026. https://doi.org/10.1061/(ASCE)GM.19435622.0001627

[25] Uge, B. U., \& Cheng, G. Y. (2019). Research Progress on the influence of deep foundation pit excavation on adjacent pile foundation. Ninth International Conference on Advances in Civil, Structural and Mechanical Engineering CSM - 2019, 12-19. https://doi.org/10.15224/978-1-63248-182-5-03

[26] Liyanapathirana, D. S., \& Nishanthan, R. (2016). Influence of deep excavation induced ground movements on adjacent piles. Tunnelling and Underground Space Technology, 52, 168-181. https://doi.org/10.1016/j.tust.2015.11.019

[27] Liang, Y.-Y., Liu, N.-W., Yu, F., Gong, X.-N., \& Chen, Y.-T. (2019). Prediction of Response of Existing Building Piles to Adjacent Deep Excavation in Soft Clay. Advances in Civil Engineering, 2019, 1-11. https://doi.org/10.1155/2019/8914708

[28] Zhang, R., Zhang, W., \& Goh, A. T. C. (2018). Numerical investigation of pile responses caused by adjacent braced excavation in soft clays. International Journal of Geotechnical Engineering, 1-15. https://doi.org/10.1080/19386362.2018.1 515810

[29] Shi, J., Wei, J., Ng, C. W. W., \& Lu, H. (2019). Stress transfer mechanisms and settlement of a floating pile due to adjacent multi-propped deep excavation in dry sand. Computers and Geotechnics, 116, 103216. https://doi.org/10.1016/j. compgeo.2019.103216

[30] Shakeel, M., \& Ng, C. W. W. (2018). Settlement and load transfer mechanism of a pile group adjacent to a deep excavation in soft clay. Computers and Geotechnics, 96, 55-72. https://doi.org/10.1016/j.compgeo.2017.10.010

[31] Soomro, M. A., Mangnejo, D. A., Bhanbhro, R., Memon, N. A., \& Memon, M. A. (2019). 3D finite element analysis of pile responses to adjacent excavation in soft clay: Effects of different excavation depths systems relative to a floating pile. Tunnelling and Underground Space Technology, 86, 138-155. https://doi.org/10.1016/j.tust.2019.01.012

[32] Ng, C. W. W., Shakeel, M., Wei, J., \& Lin, S. (2021). Performance of Existing Piled Raft and Pile Group due to Adjacent Multipropped Excavation: 3D Centrifuge and Numerical Modeling. Journal of Geotechnical and Geoenvironmental
Engineering, 147(4), 04021012. https://doi.org/10.1061/(ASCE) GT.1943-5606.0002501

[33] Li, Z., Wang, L., Lu, Y., Li, W., \& Wang, K. (2021). Effect of principal stress rotation on the stability of a roadway constructed in half-coal-rock stratum and its control technology. Arabian Journal of Geosciences, 14(4), 292. https:// doi.org/10.1007/s12517-021-06623-4

[34] Choi, J., Koo, B., \& Kim, T. (2015). Stiffness Degradation during Deep Excavation in Urban Area. Journal of the Korean GeoEnvironmental Society, 16(2), 27-31. https://doi.org/10.14481/ JKGES.2015.16.2.27

[35] Cao, Y., Liu, Y., \& Du, C. (2021). Analysis of Stress Path in the Whole Process of Foundation Pit Excavation and Heavy Lifting. IOP Conference Series: Earth and Environmental Science, 634(1), 012130. https://doi.org/10.1088/1755$1315 / 634 / 1 / 012130$

[36] Ying, H., Li, J., Xie, X., Zhu, K., \& Zhou, J. (2012). Research on stress path during excavation considering rotation of principal stress axis. Rock and Soil Mechanics, 33(4), 1013-1017.

[37] Ng, C. W. W. (1999). Stress Paths in Relation to Deep Excavations. Journal of Geotechnical and Geoenvironmental Engineering, 125(5), 357-363. https://doi.org/10.1061/ (ASCE)1090-0241(1999)125:5(357)

[38] Hsieh, P.-G., \& Ou, C.-Y. (2012). Analysis of deep excavations in clay under the undrained and plane strain condition with small strain characteristics. Journal of the Chinese Institute of Engineers, 35(5), 601-616. https://doi.org/10.1080/02533839 .2012 .679115

[39] Ni, P., Mei, G., Zhao, Y., \& Chen, H. (2018). Plane strain evaluation of stress paths for supported excavations under lateral loading and unloading. Soils and Foundations, 58(1), 146-159. https://doi.org/10.1016/j.sandf.2017.12.003

[40] Lim, A., \& Ou, C.-Y. (2017). Stress paths in deep excavations under undrained conditions and its influence on deformation analysis. Tunnelling and Underground Space Technology, 63, 118-132. https://doi.org/10.1016/j.tust.2016.12.013

[41] Liu, L., Zhang, H., \& Liu, J. (2018). Study on the Envelope of Stress Path During Deep Excavation. In W. Wu \& H.-S. Yu (Eds.), Proceedings of China-Europe Conference on Geotechnical Engineering (pp. 377-380). Springer International Publishing. https://doi.org/10.1007/978-3-319-97112-4_84

[42] Huang, M., Liu, X., Zhang, N., \& Shen, Q. (2017). Calculation of foundation pit deformation caused by deep excavation considering influence of loading and unloading. Journal of Central South University, 24(9), 2164-2171. https://doi. org/10.1007/s11771-017-3625-3

[43] Saeedi Azizkandi, A., Rasouli, H., \& Baziar, M. H. (2019). Load Sharing and Carrying Mechanism of Piles in Non-connected Pile Rafts Using a Numerical Approach. International Journal of Civil Engineering, 17(6), 793-808. https://doi.org/10.1007/ s40999-018-0356-2

[44] Guo, Y., Lv, C., Hou, S., \& Liu, Y. (2021). Experimental Study on the Pile-Soil Synergistic Mechanism of Composite Foundation with Rigid Long and Short Piles. Mathematical Problems in Engineering, 2021, 1-15. https://doi.org/10.1155/2021/6657116

[45] Samanta, M., \& Bhowmik, R. (2019). 3D numerical analysis of piled raft foundation in stone column improved soft soil. International Journal of Geotechnical Engineering, 13(5), 474-483. https://doi.org/10.1080/19386362.2017.1368139 
[46] Juang, C. H., Gong, W., Martin, J. R., \& Chen, Q. (2018). Model selection in geological and geotechnical engineering in the face of uncertainty-Does a complex model always outperform a simple model? Engineering Geology, 242, 184-196. https:// doi.org/10.1016/j.enggeo.2018.05.022

[47] Boroujeni, F. F., \& Porhoseini, R. (2020). Effect of execution process on pile group-excavation interaction. International Journal of Geotechnical Engineering. https://doi.org/10.1080/1 9386362.2020.1778155

[48] Miao, L. F., Goh, A. T. C., Wong, K. S., \& Teh, C. I. (2006). Threedimensional finite element analyses of passive pile behaviour. International Journal for Numerical and Analytical Methods in Geomechanics, 30(7), 599-613. https://doi.org/10.1002/ nag.493

[49] Yang, M., Dai, X., Zhang, M., \& Luo, H. (2016). Experimental study on earth pressure of cohesionless soil with limited width behind retaining wall. Chinese Journal of Geotechnical Engineering, 38(1), 131-137. https://doi.org/10.11779/ CJGE201601014

[50] Horikoshi, K., \& Randolph, M. F. (1997). On the definition of raft-Soil stiffness ratio for rectangular rafts. Géotechnique, 47(5), 1055-1061. https://doi.org/10.1680/geot.1997.47.5.1055

[51] Fioravante, V. (2002). On the Shaft Friction Modelling of NonDisplacement Piles in Sand. SOILS AND FOUNDATIONS, 42(2), 23-33. https://doi.org/10.3208/sandf.42.2_23

[52] National standard of the people's republic of China (JGJ 79-2012). (2012). Technical code for ground treatment of buildings. China Architecture \& Building Press.

[53] Ou, C.-Y., Teng, F., \& Li, C.-W. (2020). A simplified estimation of excavation-induced ground movements for adjacent building damage potential assessment. Tunnelling and Underground Space Technology, 106, 103561. https://doi.org/10.1016/j. tust.2020.103561

[54] Yang, Y., \& Yu, H.-S. (2013). A kinematic hardening soil model considering the principal stress rotation: MODEL THE PRINCIPAL STRESS ROTATION. International Journal for Numerical and Analytical Methods in Geomechanics, 37(13), 2106-2134. https://doi.org/10.1002/nag.2138

[55] Li, L., Huang, J., Fu, Q., Cheng, X., \& Hu, F. (2017). Centrifuge experimental study of mechanical properties of composite foundation with different replacement rates under additional load. Rock and Soil Mechanics, 38, 131-139. https://doi. org/10.16285/j.rsm.2017.S1.015

[56] Boussetta, S., Bouassida, M., \& Zouabi, M. (2016). Assessment of observed behavior of soil reinforced by rigid inclusions. Innovative Infrastructure Solutions, 1(1), 27. https://doi. org/10.1007/s41062-016-0027-6

[57] Ge, X., Zhai, X., Xue, J., \& Bai, X. (2011). Model test study of impact of pile length on long-short piles composite foundation. 2011 International Conference on Electric Technology and Civil Engineering (ICETCE), 2370-2374. https://doi.org/10.1109/ ICETCE.2011.5775233

[58] Zhang, Q.-Q., Liu, S.-W., Feng, R.-F., Qian, J.-G., \& Cui, C.-Y. (2020). Finite element prediction on the response of nonuniformly arranged pile groups considering progressive failure of pile-soil system. Frontiers of Structural and Civil Engineering, 14(4), 961-982. https://doi.org/10.1007/s11709020-0632-5

[59] Hussien, M. N., Ramadan, E. H., Hussein, M. H., Senoon, A. A. A., \& Karray, M. (2017). Load sharing ratio of pile-raft system in loose sand: An experimental investigation. International Journal of Geotechnical Engineering, 11(5), 524-529. https:// doi.org/10.1080/19386362.2016.1236224

[60] Pham, Q. N., Ohtsuka, S., Isobe, K., \& Fukumoto, Y. (2019). Group effect on ultimate lateral resistance of piles against uniform ground movement. Soils and Foundations, 59(1), 27-40. https://doi.org/10.1016/j.sandf.2018.08.013

[61] Das, B. M. (2014). Advanced soil mechanics (Fourth). CRC Press.

[62] Guo, C., Xiao, S. W., \& Chen, Z. L. (2012). Study of Low Strength Pile Composite Foundation Deformation \& Stability Calculation Method. Applied Mechanics and Materials, 170-173, 545-556. https://doi.org/10.4028/www.scientific.net/AMM.170-173.545

[63] Zhao, M., Zhang, L., \& Yang, M. (2006). Settlement calculation for long-short composite piled raft foundation. Journal of Central South University of Technology, 13, 749-754. https:// doi.org/10.1007/s11771-006-0026-4

[64] Niu, X., Yao, Y., Sun, Y., He, Y., \& Zhang, H. (2018). 3D Numerical Analysis of Synergetic Interaction between High-Rise Building Basement and CFG Piles Foundation. Applied Sciences, 8(11), 2040. https://doi.org/10.3390/app 8112040

[65] Do, N. V., Nghia, D. T., \& Tu, P. Q. (2020). Stiffness of Soil in Excavation-Induced Deformation Analysis in Vietnam. In P. Duc Long \& N. T. Dung (Eds.), Geotechnics for Sustainable Infrastructure Development (Vol. 62, pp. 351-354). Springer Singapore. https://doi.org/10.1007/978-981-15-2184-3_44

[66] Cudny, M., \& Popielski, P. (2010). Analysis of excavationinduced deformation with different soil sodels. Task Quarterly, 14(4), 339-362.

[67] Boussetta, S., Bouassida, M., Dinh, A., Canou, J., \& Dupla, J. (2012). Physical modeling of load transfer in reinforced soil by rigid inclusions. International Journal of Geotechnical Engineering, 6(3), 331-342. https://doi.org/10.3328/ IJGE.2012.06.03.331-341

[68] Bui, P., Luo, Q., Zhang, L., \& Zhang, M. (2009). Geotechnical Centrifuge Experiment Model on Analysis of Pile-Soil Load Share Ratio on Composite Foundation of High Strength Concrete Pile. International Conference on Transportation Engineering 2009, 3465-3470. https://doi. org/10.1061/41039(345)571

[69] Tran, V. D., Richard, J.-J., \& Hoang, T. (2019). Soft Soil Improvement Using Rigid Inclusions: Toward an Application for Transport Infrastructure Construction in Vietnam. In $\mathrm{H}$. Khabbaz, H. Youn, \& M. Bouassida (Eds.), New Prospects in Geotechnical Engineering Aspects of Civil Infrastructures (pp. 89-99). Springer International Publishing. https://doi. org/10.1007/978-3-319-95771-5_8 